ISSN 2476-017X

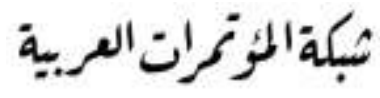

http://arab.kmshare.net/

ARF

Available online at http://proceedings.sriweb.org

The Ninth International Scientific Academic Conference

Under the Title "Contemporary trends in social, human, and natural sciences"

$$
\begin{aligned}
& \text { المؤتمر العلمي الاكاديكي الدولي التاسع - (لمع } \\
& \text { تحت عنوان "الاتحاهات المعاصرة في العلوم الاجتماعية، الانسانية، والطبيعية" } \\
& 17 \text { - } 18 \text { يوليو - تموز } 2018 \text { - اسطنبول - تركيا }
\end{aligned}
$$

http://kmshare.net/isac2018/

\title{
Analyzing the Content of the Science Textbook for 7th Grade Iraqi Schools in Light of Educational Concepts of Sustainable Development
}

\author{
Susan D. Ahmed ${ }^{\mathrm{a}}$, Majed S. Aziz ${ }^{\mathrm{b}}$, Adel K. Shabib ${ }^{\mathrm{c}}$ \\ a Baghdad University, Al- Jadrriya St., Baghdad, Iraq \\ susan_ab@yahoo.com \\ ${ }^{\mathrm{b}}$ Baghdad Univesity, Al- Jadrriya St., Baghdad, Iraq \\ mr.saeedy@yahoo.com \\ ${ }^{c}$ Baghdad Univesity, Al- Jadrriya St., Baghdad, Iraq \\ asmil6majed@gmail.com
}

\begin{abstract}
The aim of this research is to analyze the content of the science textbook for 7 th grade Iraqi schools in the light of the educational concepts of sustainable development, the science textbook (1st edition), for the academic year 2017 - 2018. To this end, the researchers prepared list of issues in the light of the educational concepts of sustainable development, consisted of (13) issues, branched to (51) subissues, presented to a group of arbitrators and specialists in science curriculum and methods of teaching. The researchers analyzed the content of the 7th grade science textbook, in the light of the list that is built, the idea has been adopted as a unit of analysis. One of the most important findings is attention to neglected sub-issues of the sustainable development as concepts and to include them in the science textbook of 7th
\end{abstract}




\section{Global Proceedings Repository \\ American Research Foundation}

ISSN 2476-017X

Available online at http://proceedings.sriweb.org

grade, and constructing a program in accordance with the educational concepts of sustainable development for students of the 7th grade in the science.

Keywords: Content Analysis, Sustainable Development, Science Textbook.

\section{Introduction}

The concept of the sustainable development began to emerge in the literature of international development in the mid-1980s. Under the influence of new concerns on the preservation of the environment and as a result of the concerns raised by studies and reports, on the need to conserve natural resources and the environment from depletion, and the basic ecosystem balances (Yahy, 2012, 73).

Despite the novelty of the term, it has been used to denote various types of human activities, such as social development, economic development and environmental development (Al-Zuwaini, Al-Arnousi, \& Hatem, 2013). The importance of the sustainable development stems from the principle that people are the focus of their attention, and they respond to the needs of the present generation without sacrificing and feeling the needs of future generations or at the expense of their ability to provide decent livelihoods. Also it is reflecting in the goals and benefits of a far-reaching perspective, for present and future, with a balanced mechanism (Shikho, 2015, 27).

It is worth mentioning, there is a close relationship between education in all its forms and levels, on the one hand, and development on the other. Education is one of the most influential factors contributing to the development of society and is an essential element of the development guide. From the generations of future will be leaders, thinkers, scientists and researchers who will change after understanding the pillars of science and progress towards the project of comprehensive sustainable development, which is one of the languages of this age (Al-Shaabani \& Yusuf, 2012; Dwikat 2000, 2-4). Education is a fundamental human right in itself, which promotes the realization of other social, cultural, economic and civil rights, that will support sustainable development and contribute to their social, economic and environmental dimensions, therefore, education of sustainable development, will help translate our vision into reality (Khadija \& AlGaelic, 2013).

Content analysis consists of two terms, one is Analysis, the other is Content. Analysis is defined as fragmentation or the breakdown of all into parts or vocabulary and linking to its main elements, content refers to the communication material that the researcher deals with for the purpose of analysis (Al-Jadri \& Abu-Helou, 2009, 5). In this type of analysis, the analysis is based on the information contained in the 


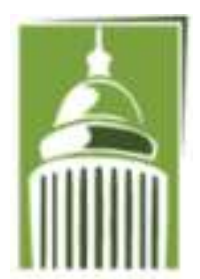

ARF

\section{Global Proceedings Repository \\ American Research Foundation}

ISSN 2476-017X

Available online at http://proceedings.sriweb.org

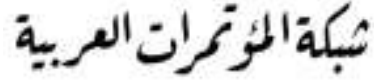

http://arab.kmshare.net/

document or documents analyzed, such as books, magazines, newspapers, laws, television programs, etc. Often, content analysis is intended to evaluate a document or a television program according to agreed

terms, criteria or standards (Al-Rokaby, 2015). Content analysis is of great importance, especially as we live in the age of accumulated knowledge, an age of tremendous revolution of informatics, which requires the judging on content and recognizing the extent to which the principles, standards and components that have been developed and quantified are respected (Mohamed \& Abdel-Adhim, 2012).

\subsection{Problem statement}

Sustainable development is one of the main and important topics in our time, to draw a clearer vision of the present and future and balance between them through planning and study. And because of its importance in improving economic and social conditions and the environment of the present and future society in general and of the citizen in particular, show the need to incorporate concepts, skills and values related to sustainable development into school curricula for the restructuring of textbooks, which in turn requires the development of mechanisms and tools to build a strategic vision based on the dimensions of sustainable development (Shikho, 2015).

The starting point of curriculum reform is analysis the content of existing curricula and to determine their compatibility with educational developments. Therefore textbooks are at the forefront of analysis, where knowledge, skills and attitudes. Curricula and books address changing issues in many ways and updating, enriching, adapting, and developing them from time to other are essential for curriculum development. Where the researcher conducted a survey of a group of science teachers of the 7th grade Iraqi schools, and found that $97 \%$ of teachers assert that the content of the science textbook for 7th grade Iraqi schools does not include the concepts of sustainable social, economic and environment issues, which led the researcher to analyze the science textbook for 7th grade Iraqi schools, which may contribute to the improvement of this science textbook by identifying the strengths to strengthen them, and weaknesses to remove them.

\subsection{Objective of the research}

The objective of the research is to analyze the content of the science textbook for 7th grade Iraqi schools, according to issues of the sustainable development concepts.

\subsection{Research question}

To what extent does the content of the science textbook for 7 th grade Iraqi schools include for issues related to the sustainable development concepts?

\subsection{Importance of the research}




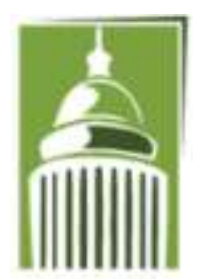

ARF

\section{Global Proceedings Repository \\ American Research Foundation}

ISSN 2476-017X

Available online at http://proceedings.sriweb.org

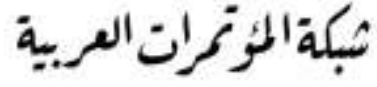

http://arab.kmshare.net/

Many of the developmental, environmental, economic and climatic crises that people face today in their various systems, the increase of poverty, deprivation, hunger, illiteracy, homelessness and ignorance

threatens to have a negative impact on the future of societies (Ibrahim, 2012, 2). This has contributed to the realization of the sustainability of the available environmental resources to create a new world with new development knowledge that is different from what existed before, so that sustainable development is one of the latest concepts of knowledge (Tawel, 2013, 12). Sustainable development is generally a major challenge for the peoples of the world because it is a continuous process that is not interrupted from generation to other and seeks progress in all areas (Tababih \& Kshiti, 2013).

The fundamental idea of sustainable development is conservation and rebalancing. Where it aims to balance the economic, social and environmental fields now and in the future, as well as the search for rational strategies that attempt to normalize society with natural systems as an integrated system that maintains its balance. The world today is convinced that sustainable development is the only way to ensure that the elements of life are present in the present and future (Al-Shammrani, 2010, 2).

Education is the true gateway to sustainable development. Because man is the engine of change, the scheme and the port of development, and for him thus development, and thus is the horizontal relationship And the vertical between sustainable development and education (Shikho, 2015, 3). Education for sustainable development is the process of reorienting education towards the sustainable development through improved education, and restructuring of existing education programs on the sustainable development and its issues and to develop understanding and awareness of individuals, communities and organizations on the sustainable development and from its objectives is training individuals for the management of the sustainable development processes (Al-Mandalawi, 2015).

Education is the basis of every development and reform, and the way that leads to the refinement of souls and the teaching of the minds and the suitability of nations, so the countries of the world turned to education to achieve the desired goals (Al-Tahan, 2006, 11).

Textbooks play an important role in achieving these goals, because they represent the most important elements of the curriculum and a key component of the curriculum. It is the most widely used educational tool in schools and is an essential tool for teaching and learning (Hillis, 2007, 1).

The researcher believes that education is the means by which society depends on local and global developments, as a tool to transfer knowledge from generation to other, through which to achieve varied and desirable changes, and thus achieve progress to society.

Since the textbook has this exclusive status in the educational process, it was necessary to provide good educational books for students and teachers to help them perform their roles and to increase the conscious use of textbooks by students and teachers (Al-Isawee, Sabri, \& Raji, 2012).

Therefore, the importance of the research concentrates in the following:

1. To provide an objective instrument for analyzing the content of the science textbook for 7 th grade Iraqi schools, which may benefit other researchers in the analysis of other textbooks for intermediate and preparatory stage in the light of educational concepts of sustainable development. 


\section{Global Proceedings Repository \\ American Research Foundation}

ISSN 2476-017X

Available online at http://proceedings.sriweb.org

2. Analysis of the science textbook for 7th grade Iraqi schools, as one of the textbooks that were written recently and not subject to prior analysis.

3. Based on findings of the process of analysis can make improvements and amendments for the science textbooks.

\subsection{Limitations of Research}

The research was limited to the following:

1. The science textbook for 7th grade Iraqi schools ( $1^{\text {st }}$ edition) for the academic year 2017-2018.

2. Concepts of the sustainable development.

\section{Definition of terminology}

In this research, there are some terms need to definite and clarify, as following:

\subsection{Content analysis}

Al-Laqani and Jamal (2003), defined it 'as a method that is used along with other approaches to evaluate the curriculum for its development. It is based on the objectives of the analysis to come up with indicators that determine the direction of development later'(Al-Laqani \& Jamal, 2003, 86). Samara and Musa (2008), 'as a method of scientific research aimed at the objective, systematic and quantitative description of the apparent content of the communication material or the lack of information in the content of the communication materials ,the analysis unit has been used to determine the prevalence of a phenomenon, concept or idea lack of information in the content of printed communication materials'(Samara \& Musa, 2008, 53).

The researcher defines the content analysis is as 'an analytical process of the content of the science textbook for 7th grade Iraqi schools to identify what this book contains concepts of the sustainable development, as represented by social, economic and environment'.

\subsection{Concepts of the sustainable development}

Concepts of the sustainable development, have been defined by: Kasim (2010) as 'development that meets the needs of the present without compromising the ability of future generations to meet their needs' (Kasim, 2010, 20). Al-Shafi'i (2012) 'as development based on the principle of The optimal utilization of available resources to raise the standard of living that includes future generations alongside the present generation'(Al-Shafi'i, 2012, 13).

The researcher defines them as' concepts that express their concern for the present and future generations of human beings in all human, social, economic and environmental dimensions in order to provide them with a decent livelihood. It will be recognized the amount of fulfillment of the science textbook for 7th grade Iraqi schools after analyze its content. 


\section{Global Proceedings Repository \\ American Research Foundation}

ISSN 2476-017X

ARF

Available online at http://proceedings.sriweb.org

\subsubsection{Social concept}

Social concept of sustainable development means securing the basic needs of people living in extreme poverty (education, health care and clean water), as well as improving social welfare, protecting cultural diversity, investing in human resources, which call for continued development (Saudi Arabia, 2005, 45).

\subsubsection{Economic concept}

Sustainable economic system is to allow the production of goods and services to satisfy humanity and achieve prosperity on an ongoing basis without harming the natural environment and to seek effective ways to meet economic needs without harming the environment, to reduce pollution of the environment and treatment of surface water, groundwater, soil, diseases and epidemics to avoid their polluted effects (AbdulJalil, 2014, 219).

\subsubsection{Environment concept}

Which is the backbone of sustainable development, all of our movements are based primarily on the quantity and type of natural resources. And environmental depletion is one of the factors that conflict with the sustainable development. Therefore, we need scientific knowledge of natural resource management for many years to come, in order to obtain systematic and interrelated methods with the management of the ecosystem to prevent further stress (Deep \& Mahana, 2009,4).

\section{Research methodology}

The researcher followed the analytical descriptive method to analyze the content of the science textbook for 7th grade Iraqi schools in light of educational concepts of the sustainable development, which depends on studying the phenomenon as it exists in reality and describing it accurately and expressing it quantitatively (Al-Assaf, 2006, 236). The researcher adopted a method of analyzing the content to achieve the research objective, because it is characterized by the characteristics of systematic scientific research, from the objectivity, impartiality, regularity and scalability of the dissemination of the results that reach it, and it is the appropriate method for this research (Attia, 2010, 198).

\subsection{Community and sample of the research}


ISSN 2476-017X

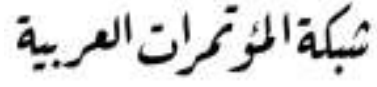

http://arab.kmshare.net/

ARF

Available online at http://proceedings.sriweb.org

The community of research is determined by the science textbook for 7 th grade Iraqi schools (1st edition), for the academic year 2017 - 2018. The identification of the research society is one of the methodological steps in educational research.

The sample of research is a content of the science textbook for 7th grade Iraqi schools, the total pages of the science textbook content are 235 pages, after excluding the questions of the science textbook, remain 190 pages that are analyzed, which represent almost $81 \%$ of the total pages, as shown in Table 1.

Table 1. Science textbook for 7th grade Iraqi schools

\begin{tabular}{ccccccc}
\hline Analyzed Pages & Total Pages & Year & $\begin{array}{c}\text { Number of } \\
\text { Chapters }\end{array}$ & Edition & Grade & $\begin{array}{c}\text { Textbook } \\
\text { Title }\end{array}$ \\
\hline 190 & 235 & 2016 & 13 & 1 st & $\begin{array}{c}7^{\text {th }} \text { Iraqi } \\
\text { Schools }\end{array}$ & Science \\
\hline
\end{tabular}

\subsection{Research instrument}

In order to reach the goal of the research, it is necessary to adopt a list of the concepts of sustainable development that should be available in the content of the science textbook for 7 th grade Iraqi schools. In order to analyze the content of the science textbook in light of the concepts of sustainable development.

After review previous literature and studies on the sustainable development, the researcher adopt and adapt the research instrument of Al-Raziky (2016), that its preliminary form includes (56) sub-issues of the sustainable development, distributed on (13) major issues of three concepts, as represented by the social concept, economic concept, and environment concept.

\subsection{Validity of the research instrument}

The preliminary form of the research instrument was presented to the team of arbitrators. Based on view of the team of arbitrators, the researcher delete five sub-issues out of (56) sub-issues, so the final form of the research instrument includes (51) sub-issues. As well as some issues have been modified and changed. Thus, the research instrument was validity and usable.

\subsection{Procedures of the content analysis}

The researcher adopted the explicit idea as a unit of analysis, because the science textbook for 7 th grade Iraqi schools, comes most of its expressions in an explicit and clear, so does not require much interpretation. Furthermore, the researcher adopted repetition as the enumeration unit. To test the validity of 


\section{Global Proceedings Repository \\ American Research Foundation}

ISSN 2476-017X

Available online at http://proceedings.sriweb.org

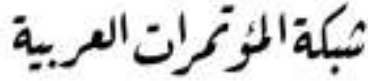

http://arab.kmshare.net/

the analysis, a sample of the content analysis has been presented to a number of arbitrators, who in turn appeared approval on the validity of the analysis process. Reliability coefficients have been established, as shown in Table 2.

Table 2. Reliability coefficients of the analysis

\begin{tabular}{ccc}
\hline $\begin{array}{c}\text { Reliability } \\
\text { Coefficients }\end{array}$ & Between the Researcher and & Agreement \\
\hline 0.91 & himself after 30 days & Over the Time \\
\hline 0.83 & $1^{\text {st }}$ analyst & Between the Analysts \\
0.89 & $2^{\text {nd }}$ analyst \\
0.77 & $1^{\text {st }}$ and $2^{\text {nd }}$ analysts & \\
\hline
\end{tabular}

Thus the reliability coefficients of this research are good, according to the previous literature, that indicate if the value of the reliability coefficient is more than 70, it is good (Al-Jadri, \& Abu-Helou, 2009).

\subsection{Presentation and interpretation the findings}

Overall, the results of the analysis of the content of the science textbook for 7th grade Iraqi schools showed frequencies and percentages of sub-issues, distributed on major issues of the concepts of the sustainable development, as represented by economic, environment, and social concept, that exist in the content of the science textbook, as shown in Table 3 .

Table 3. Frequencies and percentages of sub-issues in major issues of the concepts of the sustainable development

\begin{tabular}{|c|c|c|c|c|}
\hline \multirow[t]{2}{*}{ No. } & \multirow[t]{2}{*}{ Concept } & \multirow{2}{*}{$\begin{array}{c}\text { Major Issues } \\
\text { Number }\end{array}$} & \multicolumn{2}{|c|}{ Sub-Issues } \\
\hline & & & Frequency & Percentage \\
\hline 1 & Social & 6 & 58 & $73.4 \%$ \\
\hline 2 & Economic & 2 & 17 & $21.5 \%$ \\
\hline 3 & Environment & 5 & 4 & $5.10 \%$ \\
\hline & Total & 13 & 79 & $100 \%$ \\
\hline
\end{tabular}

The major issues of the social concept, as represent by health and education, their frequencies and percentages of the sub-issues, exist in the content of the science textbook for 7th grade Iraqi schools, but other major issues which are social justice, population, housing, and security have been neglected and do not found their sub-issues in the content of the science textbook for 7th grade Iraqi schools, as shown in Table 4. 


\section{Global Proceedings Repository \\ American Research Foundation}

ISSN 2476-017X

Available online at http://proceedings.sriweb.org

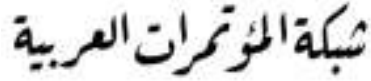

http://arab.kmshare.net/

Table 4. Frequencies and percentages of sub-issues in major issues of the social concept

\begin{tabular}{|c|c|c|c|}
\hline & \multicolumn{3}{|c}{ Social Concept } \\
\hline No. & Major Issues & \multicolumn{2}{c|}{ Sub-Issues } \\
\hline 1 & & Frequency & Percentage \\
\hline 2 & Social justice & 0 & $0 \%$ \\
\hline 3 & Health & 5 & $8.62 \%$ \\
\hline 4 & Education & 53 & $91.38 \%$ \\
\hline 5 & Population & 0 & $0 \%$ \\
\hline 6 & Housing & 0 & $0 \%$ \\
\hline & Security & 0 & $0 \%$ \\
\hline
\end{tabular}

The major issues of the economic concept, as represent by the economic development and production or consuming, their frequencies and percentages of the sub-issues exist in the content of the science textbook for 7 th grade Iraqi schools, as shown in Table 5.

Table 5. Frequencies and percentages of sub-issues in major issues of the economic concept

\begin{tabular}{|c|c|c|c|}
\hline \multicolumn{4}{|c|}{ Economic Concept } \\
\hline \multirow{2}{*}{ No. } & \multirow{2}{*}{ Major Issues } & \multicolumn{2}{|c|}{ Sub-Issues } \\
\hline & & Frequency & Percentage \\
\hline 1 & Economic Development & 11 & $64.71 \%$ \\
\hline 2 & Production or Consuming & 6 & $35.29 \%$ \\
\hline \multicolumn{2}{|c|}{ Total } & 17 & $100 \%$ \\
\hline
\end{tabular}

The major issues of the environment concept, as represent by atmosphere, lands, and freshwater, their frequencies and percentages of the sub-issues exist in the content of the science textbook for 7 th grade Iraqi schools, but other major issues which are biodiversity and seas or oceans, have been neglected and do not found their sub-issues in content of the science textbook for 7th grade Iraqi schools, as shown in Table 6.

Table 6. Frequencies and percentages of sub-issues in major issues of the environment concept

\begin{tabular}{|c|c|c|c|}
\hline \multicolumn{4}{|c|}{ Environment Concept } \\
\hline \multirow[t]{2}{*}{ No. } & \multirow[t]{2}{*}{ Major Issues } & \multicolumn{2}{|c|}{ Sub-Issues } \\
\hline & & Frequency & Percentage \\
\hline 1 & Atmosphere & 1 & $25 \%$ \\
\hline 2 & Lands & 1 & $25 \%$ \\
\hline
\end{tabular}




\section{Global Proceedings Repository \\ American Research Foundation}

ISSN 2476-017X

Available online at http://proceedings. sriweb.org

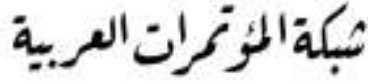

http://arab.kmshare.net/

\begin{tabular}{|c|c|c|c|}
\hline 3 & Biodiversity & 0 & $0 \%$ \\
\hline 4 & Seas or Oceans & 0 & $0 \%$ \\
\hline 5 & Freshwater & 2 & $50 \%$ \\
\hline & & 4 & $100 \%$ \\
\hline
\end{tabular}

From the foregoing, the frequencies and percentages of sub-issues in the content of the science textbook for 7th grade Iraqi schools are not balanced. whereas the focus is on the social concept, followed by the economic concept, and finally the environment concept, which is very low compared to other concepts.

The other sub-issues did not get any repetition. So, the researcher believes that the non-representation or low-representation of these sub-issues of all concepts, particularly with regard to the environment concept, is a negative indicator for the textbook,

The authors of the science textbooks should stand before these issues and try to include them in the books because of their importance as aiming at the complete construction of the students' personality, as well as to help and enable them to contribute a useful and effective role in society now and in the future.

\subsection{Conclusion}

The findings indicate that the content of the science textbook for 7th grade Iraqi schools, has neglected many of the sub-issues of each concept, which means there is a weakness in the content of the science textbook for 7th grade Iraqi schools and its subjects. Moreover, the frequencies and percentages of some sub-issues in the content of the science textbook for 7th grade Iraqi schools are not balanced.

\subsection{Recommendations}

In the light of the findings of the research, the researcher recommends to do balance in the proportions of inclusion the sub-issues of all concepts of the sustainable development in the content of the science textbook for 7th grade Iraqi schools, so as not to overwhelm a concept over the rest of the concepts. As well as, taking care of the neglected the sub-issues of all concepts and include them in in the content of the science textbook for 7 th grade Iraqi schools.

\section{References}




\section{Global Proceedings Repository \\ American Research Foundation}

ISSN 2476-017X

Available online at http://proceedings.sriweb.org

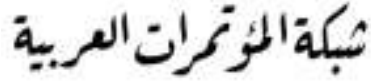

http://arab.kmshare.net/

Abdul-Jalil, A. H. (2014). The interactive relationship between ecotourism and sustainable development. Journal of Studies and Social Research, No. 9, p 211-225.

Al-Assaf, S. H. (2006). Introduction to research in behavioral science. 4th Ed., Al-Obeikan Library, AlRiyadh.

Al-Isawee, R. A., Sabri, D. A., \& Raji, Z. H. (2012). The curriculum and the textbook. Noor Al-Hassan Library, Baghdad.

Al-Jadri, A. H., \& Abu-Helou, Y. A. (2009). The methodological basis and statistical uses in the educational science research. Dar Al-Ethraa, Amman.

Al-Laqani, A. H., \& Jamal, A. A. (2003). The educational glossary of the educational terms and knowledge in curricula and teaching methods. $3^{\text {rd }}$ Ed., Aalam Al-Kitab, Cairo.

Al-Mandalawi, A. K., (2015). 'Evaluation of Arabic language textbooks for the 6th grade in the light of the dimensions of the sustainable educational development', Master thesis, College of Education/ Ibn Rushd, University of Baghdad.

Al-Raziky, W. M. (2016). "Analysis of the content of science textbooks for primary schools according to the dimensions of sustainable development", Doctoral dissertation, College of Education for Pure Sciences/ Ibn Al-Haytham, University of Baghdad.

Al-Rokaby, F. S. (2015). 'Analysis of computer books content for the intermediate stage in the light of the objectives of the teaching material'. Master thesis, College of Education for Pure Sciences/ Ibn AlHaytham, University of Baghdad.

Al-Shaabani, S., \& Yusuf, K. (2012). The role of environmental disclosure in support of sustainable development. Journal of Business and Economics, thirty-fifth year, No. 93, P (1-13).

Al-Shafi'i, H. (2012). Sustainable development and accounting and auditing of environment on physical education and sport, Dar Al-Wafaa, Alexandria.

Al-Shammrani, S. I. (2010). 'Sustainable development in the Arab region: reality and hopefully'. Master thesis, College of the Business Administration, University of Almalik Suad, Al-Riyadh.

Al-Tahan, M. M. (2006). Education and its role in behavior formation. Dar Al-Maarefa, Beirut.

Al-Zuwaini, I. S., Al-Arnousi, D. U., \& Hatem, H. D. (2013). Curriculum and Analysis of book. $1^{\text {st }}$ Ed., Dar Safaa, Amman.

Attia, M. A. (2010). Scientific research in education, its curricula - tools - statistical methods. Dar AlManahj, Amman.

Deep, R. D., \& Mahana, S. U. (2009). Planning for sustainable development. Journal of the University of Damascus for Engineering Science, volume 25, No. 1, p1-34.

Dwikat, K. A. (2000). The role of graduate studies and research in achieving the sustainable development in Palestine. Al-Quds University, Palestine.

Hillis, D. D. (2007). Evaluative study of textbook quality standards and specifications for primary students. Research has been presented in the third conference (Quality Palestinian education, introduction for excellence), College of Education, Islamic University, Gaza. 


\section{Global Proceedings Repository \\ American Research Foundation}

ISSN 2476-017X

Available online at http://proceedings.sriweb.org

Ibrahim, M. I. (2012). Analysis of science books of the secondary stage in Sudan in light of the concepts of sustainable development. University of Khartoum, Faculty of Science, Khartoum.

Kasim, K. M. (2010). Department of the environment and sustainable development. Almanar Al-Chamah press, Alexandria.

Khadija, A. U., \& Al-Ghalia, A. M. (2013). 'Problematic of the sustainable development in Algeria'. A licentiate in political sciences. Kasdi Merbah-Wargla.

Mohamed, W. A., \& Abdel-Adhim, R. A. (2012). Content analysis of science curriculum. $1^{\text {st }}$ Ed., Dar AlMasirah, Amman.

Samara, N. A., \& Udayli, A. M. (2008). Concepts and terms in educational science. $1^{\text {st }}$ Ed., Dar AlMasirah, Amman.

Saudi Arabia, Ministry of Municipal and Rural Affairs, (2005). Manual activation of sustainable development in planning. $1^{\text {st }}$ Ed., Al-Riyadh.

Shikho, A. A. (2015). 'The role of non-governmental organizations in supporting education to achieve sustainable development in Gaza governorates and ways to develop it'. Master Thesis, Gaza.

Tababih, S. N., \& Kshiti, H. D. (2013). The role of Islamic monetary policies in achieving sustainable development. Research presented to participate in the ninth international conference of (Islamic economics and finance), University of 8 May 1945 Galma, Algeria.

Tawel, F. U. (2013). "Environmental education and its role in sustainable development". Doctoral dissertation, School of Humanities and Social Sciences, University of Mohamed Khider-Biskra, Algeria.

Yahy, M. N. (2012). Value of work in Islam and its role in sustainable development. Research has been presented in the International Forum on the components of achieving the sustainable development in the Islamic economy, University of Galma, Algeria. 